DOI: 10.15740/HAS/IJAS/12.2/382-384

\title{
Evaluation of rice varieties for aerobic soil condition of eastern Uttar Pradesh
}

\author{
D.K. VERMA, ALOK PANDEY*, SAURABH VERMA', KUMUD SINGH, S.P. GIRI, R.B. SINGH ${ }^{2}$, R.P. \\ SINGH $^{3}$ AND RAM GOPAL ${ }^{4}$ \\ Crop Research Station (N.D.U.A.T.), Masodha, FAIZABAD (U.P.) INDIA \\ (Email : alokpandey77@live.com)
}

\begin{abstract}
A field experiment was conducted to evaluate popular rice varieties viz., NDR 97, Sushk Samrat, NDR 359, Sarjoo-52, Sahbhagidhan, Arize 6444 and IR 64 in Randomized Block Design with three replications in aerobic rice production system in eastern Uttar Pradesh. Among the rice varieties Sarjoo-52 was found most promising and produced highest grain yield of 5.10 t $\mathrm{ha}^{-1}$ in aerobic soil of eastern Uttar Pradesh. The next best variety was Arize $6444\left(4.75 \mathrm{tha}^{-1}\right)$ and it was at par with NDR 359 (4.23 $\left.\mathrm{t} \mathrm{ha}^{-1}\right)$ and IR $64\left(3.58 \mathrm{tha}^{-1}\right)$.
\end{abstract}

Key Words : Rice varieties, Aerobic soil condition

View Point Article : Verma, D.K., Pandey, Alok, Verma, Saurabh, Singh, Kumud, Giri, S.P., Singh, R.B., Singh, R.P. and Gopal, Ram (2016). Evaluation of rice varieties for aerobic soil condition of eastern Uttar Pradesh. Internat. J. agric. Sci., 12 (2) : 382-384, DOI:10.15740/HAS/ IJAS/12.2/382-384.

Article History : Received : 05.04.2016; Accepted : 30.05 .2016

\footnotetext{
* Author for correspondence:

${ }^{1}$ Krishi Vigyan Kendra, Pilkhi, MAU (U.P.) INDIA

${ }^{2}$ Department of Seed Technology, Narendra Dev University of Agriculture and Technology, Kumarganj, FAIZABAD (U.P.) INDIA

${ }^{3}$ Department of Agronomy, Narendra Dev University of Agriculture and Technology, Kumarganj, FAIZABAD (U.P.) INDIA

${ }^{4}$ Krishi Vigyan Kendra, Masodha, FAIZABAD (U.P.) INDIA
} 